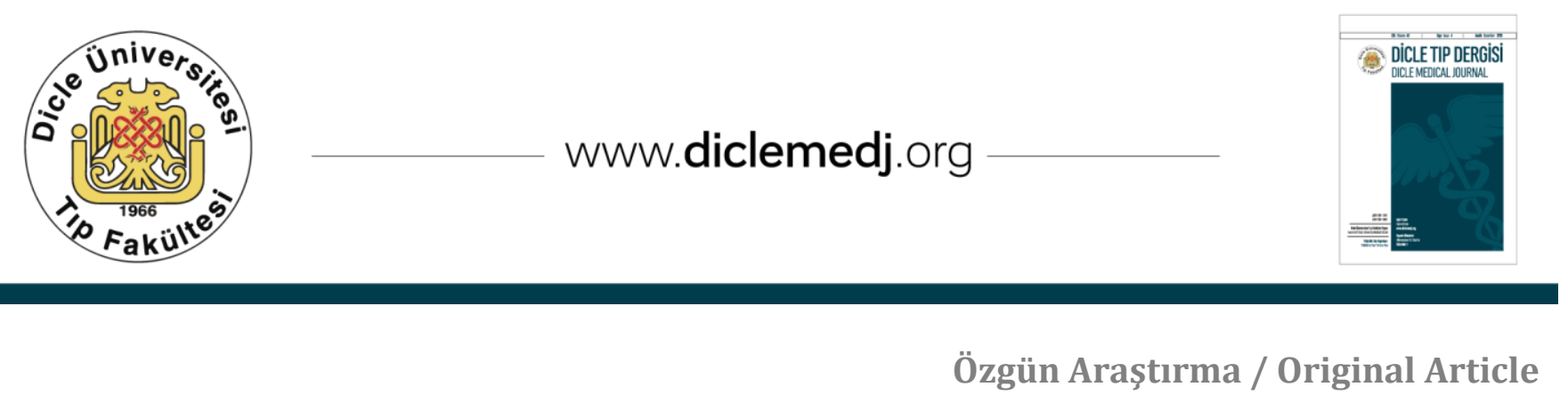

\title{
Inter-stimulus Interval Effect on Tactile Habituation: An Electrophysiological Approach
}

\author{
Güliz Akın¹, Çağdaş Güdücü² \\ 1 Dokuz Eylül University, Faculty of Medicine, Department of Biophysics, 35340, Balçova, Izmir, Turkey ORCID: 0000-0002-9612-6577 \\ 2 Dokuz Eylül University, Faculty of Medicine, Department of Biophysics, 35340, Balçova, Izmir, Turkey ORCID: 0000-0002-7735-4048
}

Received: 31.12.2018; Revised: 21.03.2019; Accepted: 26.03.2019

\begin{abstract}
Objective: The current study aims to investigate different inter-stimulus interval effect on habituation process by using non-painful tactile stimuli.

Methods: Twelve right-handed healthy volunteers (6 female; mean age: $22.9 \pm 1.93$ years) participated to the study. The electroencephalography (EEG) was recorded from 64 channels. Non-painful tactile stimuli $(\sim 140 \mathrm{kPa})$ were delivered to the right index finger via using a pneumatic stimulator. Somatosensory evoked potentials (SEP) paradigm was used in all session. Inter-stimulus interval (ISI) was selected as 2s, 4s, and $8 \mathrm{~s}$ and applied in separate sessions (as $\mathrm{ISI}_{2}, \mathrm{ISI}_{4}$ and $\mathrm{ISI}_{8}$ ).

Results: Peak-to-peak maximum amplitudes of N2, P3 and N4 components were measured for three different ISI and for three different electrode sites (Fz, Cz, Pz). The 3x3 repeated measures ANOVA test was employed for statistical analysis. According to the analysis, a significant inter-stimulus interval (ISI) effect was found on both PPmax $2 \mathrm{~N}_{2}$ and PPmaxрзм4 ( $\mathrm{p}=0.004$ and $\mathrm{p}=0.001$ respectively). The amplitudes of ISI 8 session in all electrode sites higher than ISI $_{2}$

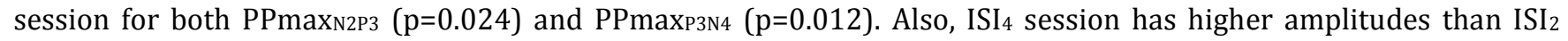
session $(\mathrm{p}=0.05)$ for the PPmaXP3N4.

Conclusion: This study revealed that the late components of SEPs are affected by the ISI change. The amplitudes of SEP components are increased as ISI increased.
\end{abstract}

Keyword: Non-painful tactile stimuli, habituation, inter-stimulus interval, electroencephalography.

DOI: $10.5798 /$ dicletip

Yazışma Adresi / Correspondence: Çağdaş Güdücü, Dokuz Eylül University, Department of Biophysics, 35340, Balçova, Izmir, Turkey e-mail: cagdas.guducu@deu.edu.tr 


\section{Uyaranlar Arası Sürenin Ağrısız Dokunsal Uyaran Yanıtlarına Etkisi: Elektrofizyolojik Yaklaşım}

\section{Öz}

Amaç: Bu çalıșma farklı uyaranlar arası sürenin ağrısız dokunsal uyaranlar üzerindeki etkilerini ortaya koymayı amaçlamaktadır.

Yöntem: Çalışmaya sağ elini kullanan 12 gönüllü ( 6 kadın; yaş ortalaması: 22,9 \pm 1,93 yıl) katılmıştır. Katılımcıların sağ el işaret parmağı pulpasına ağrısız dokunsal uyaran $(\sim 140 \mathrm{kPa})$ pnömatik uyarıcı ünitesi aracıllğı ile uygulanmıștır. Katılımcılara tüm oturumlarda dokunsal uyarılma potansiyeli paradigması (Somatosensory evoked potentials-SEP) uygulanmış ve oturum süresince elektroensefalografi (EEG) kayıtları alınmıştır. Uyaranlar arası süre $2 \mathrm{~s}$, $4 \mathrm{~s}$ ve $8 \mathrm{~s}$ olarak seçilmiş ve ayrı oturumlar $\left(\mathrm{ISI}_{2}, \mathrm{ISI}_{4}\right.$ ve ISI $\left.{ }_{8}\right)$ şeklinde katılımcılara uygulanmıştır.

Bulgular: Ağrısız dokunsal uyarana karşı oluşan yanıtların koldan kola en yüksek genlik ölçümleri N2, P3 ve N4 bileşenleri için üç farklı uyaranlar arası sürede ve üç farklı elektrot bölgesinde (Fz, Cz ve Pz) yapılmıștır. Her üç elektrot bölgesi için de en büyük genlikler ISI8 oturumunda gözlenmiştir. Tekrarlı ANOVA testi sonuçlarına göre $\operatorname{PPmax}_{\mathrm{N} 2 \mathrm{P} 3}$ ve PPmaxP3N4 için anlamlı bir uyaranlar arası süre etkisi bulunmuştur (sırasıyla $\mathrm{p}=0,004 ; \mathrm{p}=0,001$ ). İkili karşılaştırmalar sonucunda, ISI8 oturumundaki PPmax 2 2 3 ve PPmaxP3N4 için oluşan genliklerin ISI 2 oturumundaki genliklerden anlamlı olarak büyük olduğu bulunmuştur (sırasıyla $\mathrm{p}=0,024 ; \mathrm{p}=0,012$ ). Ayrıca $\mathrm{ISI}_{4}$ oturumunda oluşan $\mathrm{PPmax}_{3 \mathrm{~N}_{4}}$ genlikleri ISI 2 oturumundaki genliklerden anlamlı olarak büyüktür $(\mathrm{p}=0,05)$.

Sonuç: Bu çalışma, ağrısız dokunsal uyaranlara karşı oluşan beyin yanıtlarındaki geç bileşenlerin uyaranlar arası süre değişiminden etkilendiğini ortaya koymuştur. Uyaranlar arası süre arttıkça uyaranlara karşı oluşan beyin yanıtlarının genliklerinde artış gözlenmiştir.

Anahtar kelimeler: Ağrısız dokunsal uyaran, uyum, uyaranlar arası süre, elektroensefalografi

\section{INTRODUCTION}

The phenomenon of habituation has been observed during the process of repetitive stimuli within a wide range of organisms from amoeba to highly organized organisms such as amphibians, reptiles, birds, humans and some plants ${ }^{1}$. This process basically prevents cortical areas from the irrelevant information and this way organism can save time and energy to distinguish the relevant sensory inputs from the multisensory world ${ }^{2}$. The studies generally focused to the habituation mechanisms of human auditory and visual systems. Despite the importance, especially during the perception of the outside world from the early stage of lifespan $^{3}$ include variety in sensation such as pressure, pain, temperature and muscle sense, habituation mechanisms of human somatosensory system was studied in a relatively few number of studies. Generally, somatosensory perception and the possible habituation mechanisms are investigated by using the painful or mechanical (electrical, laser, heat, vibration and rotation) stimuli in the literature ${ }^{4-8}$.

Nowadays, with the development of the technology, the haptic feedback became a very important topic in scientific research including the invasive surgery, electromechanical graphics and haptics added to mobile phones and large-scale displays. Beyond the haptic feedback, the basic habituation mechanisms of the tactile or touch stimuli became to an important topic for the researchers ${ }^{9}$. It is known that the cortical responses to tactile (non-painful) and nociceptive (painful) processing have different temporal and spatial activation patterns ${ }^{10-12}$. But the habituation mechanisms of tactile stimulation are not clear yet in regard to electrophysiology. Interstimulus interval manipulation is one of the valid methods to investigate the habituation on somatosensory perception in healthy individuals and patients ${ }^{13}$. In these studies, the 
pain habituation has been studied well but the effects of inter-stimulus interval on habituation by using touch stimulus have not been investigated until now.

In this context, the current study aimed to investigate the effect of different inter-stimulus interval on the habituation process by using non-painful tactile stimulation.

\section{METHODS}

Twelve right-handed healthy volunteers (6 female; mean age: $22.9 \pm 1.93$ years) participated to the study. The handedness was evaluated by a Turkish version of the Edinburgh Handedness Inventory. None of the participants have any self-reported neurological, psychological or chronic diseases. The local ethical committee of the university approved the study (EK2018/12-29) and all of the participants signed the informed consent before the attendance to the study.

Brain responses recorded via 64 channel electroencephalography (EEG, Neuroscan 4.2, Synamps, USA) while participants were seated in a comfortable chair in a room with an electromagnetic shield and sound isolation. Embedded Microcontroller Stimulation Unit (EMISU) ${ }^{14}$ and additional equipment such as video recording system and analysis computer were used during the recordings.

For the EEG recordings a specific 64 channel cap (Quik Caps, Compumedics, USA) was used and were placed according to the international 10-10 electrode positions system ${ }^{15}$. For the references, earlobes were linked [(A1+A2)/2] with $\mathrm{Ag} / \mathrm{AgCl}$ electrodes. Additionally, $\mathrm{Ag} / \mathrm{AgCl}$ electrodes were placed to the outer canthus of the left and right eyes for the electrooculography (EOG) recordings to monitor the eye movements. Both the reference and EOG electrodes were filled with the EEG paste (EEG Paste-z401CE, Japan), while the cap electrodes were filled with the EEG gel (Neurogel-Genova/Italy) to reduce the impedance. All impedance values were kept under the $10 \mathrm{k} \Omega$.

Non-painful tactile stimulations were delivered via a pneumatic stimulation unit (Somatosensory Stimulus Generator 4-D Neuroimaging, USA) and was applied to the index finger pulp of the right hand via clips which have moving membrane under the constant air pressure (Figure 1). The air pressure for the stimulus was set at $\sim 140 \mathrm{kPa}$. The time of the delivered stimulus to the subject was marked to the EEG for the offline analysis.

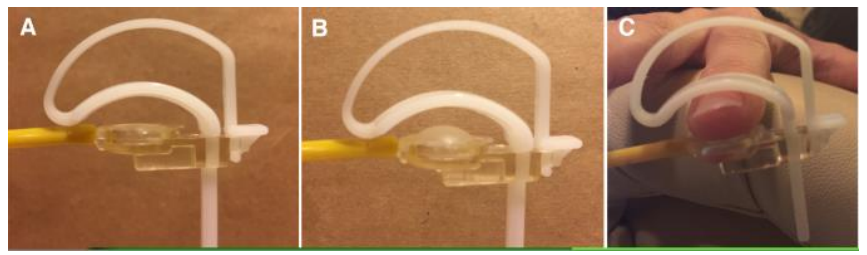

Figure 1: Non-painful tactile stimulus delivered via clips which has been demonstrated in the figure. (A) is the membrane without stimulus, (B) with stimulus in the clips and (C) while the finger is placed.

Participants came to the laboratory in two different days. In the first day, the environment of the EEG room and the experimental protocol were introduced to the participants. In the second day, all participants filled the forms (incl. informed consent and personal information form) and scales (incl. Edinburgh Handedness Test, Epworth Sleepiness Scale, The State Trait Anxiety Inventory-STAI-TX1) and they attended to the whole experimental procedure. Somatosensory evoked potential (SEP) paradigm was used in all recordings. Inter-stimulus interval (ISI) was selected as $2 \mathrm{~s}$, $4 \mathrm{~s}$, and $8 \mathrm{~s}$ and applied as separate sessions with a randomized order for each participant. The stimuli were presented as 40 times in each session and total stimulus duration $200 \mathrm{~ms}$. Therefore, all participants received a total of 120 stimuli. Additionally, there was approximately 5 minutes resting period 
between the sessions. During the recordings, the subjects were instructed to keep their eyes at a fixation point located on the computer screen and ignore the stimuli.

For the sake of simplicity, three electrodes (Fz, $\mathrm{Cz}$, and $\mathrm{Pz}$ ) were analyzed primarily. Off-line analysis was conducted to reveal the brain responses to the non-painful tactile stimuli. The off-line analysis procedure contains cutting epochs, baseline correction, artefact rejection, filtering and averaging. As a first step, eye blinks and eye movements were extracted from the continuous EEG by using a tool, based on Independent Component Analysis, on the Scan 4.5 software (Neuroscan Inc., USA). Then, the epochs were created by cutting the continuous data from $-1000 \mathrm{~ms}$ (pre-stimulus) to $1000 \mathrm{~ms}$ (post-stimulus). The epochs, which contained greater than $\pm 50 \mu \mathrm{V}$ amplitudes were also rejected. Then, remaining epochs were corrected to the baseline by using pre-stimulus interval and filtered with a $0.5-48 \mathrm{~Hz}$ bandpass filter (12 dB/octave gain and zero phase shift). In the last step of the analysis, the individual average files were created and they were used for the peak to peak maximum (PPmax) amplitude measurements. In the literature, there are many different notations for the SEP components. In this study we demonstrate the peaks N200 as N2, P300 as P3 and N400 as N4. Therefore, the PPmaxn2P3 and PPmaXP3N4 calculated by subtracting the amplitude of N2 from the amplitude of P3 and N4 from P3 respectively (See Figure 2).

\section{Statistical Analysis}

SPSS software (v24, IBM, USA) was employed for the statistical analysis. A two-way $3 \times 3$ repeated measures ANOVA (rm-ANOVA) was applied for the statistical evaluation. The peakto-peak maximum amplitudes were measured for three different inter-stimulus intervals $(2 \mathrm{~s}$, $4 s$, and 8s) in three different electrode locations (Fz, $\mathrm{Cz}$ and $\mathrm{Pz}$ ). ISI and electrode positions were analyzed as within subject factors. In all cases, the sphericity was maintained. Significance level was selected as 0.05 for all comparisons. Additionally, Bonferroni correction was applied to the pairwise comparisons.

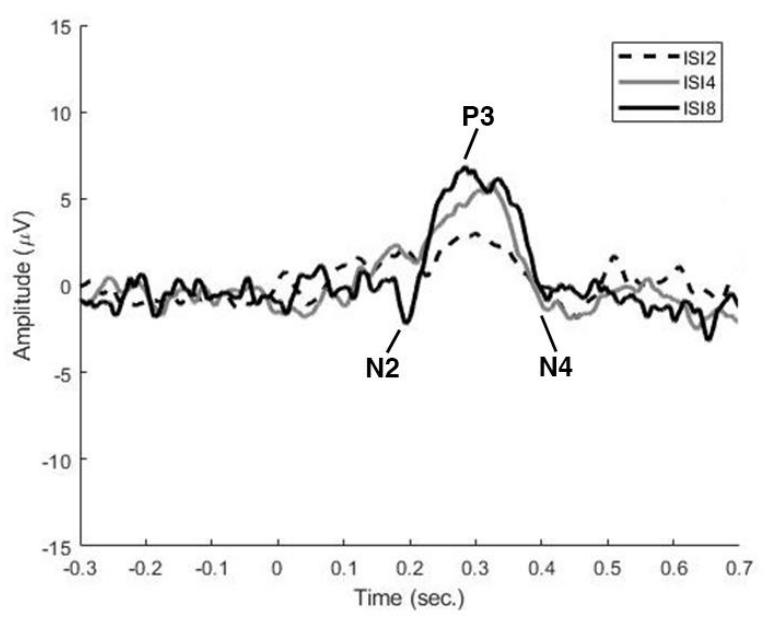

Figure 2: Grand averages of Somatosensory Evoked Potentials (SEP) are demonstrated in $\mathrm{Cz}$ electrode for three inter-stimulus interval sessions $(2 \mathrm{~s}, 4 \mathrm{~s}$, and $8 \mathrm{~s})$. The horizontal axis denotes times in seconds, while the vertical axis denotes amplitudes of responses to non-painful tactile stimuli in microvolts $(\mu \mathrm{V})$. Time zero " 0 " represents the stimulation time. Peak to peak amplitude measurements were done according to the N2, P3 and N4 components.

\section{RESULTS}

PPmaxN2P3 and PPmaxp3n4 amplitudes were measured for all participants in three different electrodes and three different ISI sessions. According to the rm-ANOVA, a significant interstimulus interval (ISI) effect was found on both $\left.\operatorname{PPmax}_{\mathrm{N} 2 \mathrm{P} 3} \mathrm{~F}(2,22)=7.17 ; \eta^{2}=.395 ; \mathrm{p}=0.004\right)$ and PPmaxP3N4 $\left.F(2,22)=8.93 ; \eta^{2}=.448 ; p=0.001\right)$. To reveal the significant differences between the ISI's, pairwise comparisons were employed. According to these comparisons, ISI8 session has significantly higher amplitudes than ISI2 session $(\mathrm{p}=0.024)$, and the amplitudes of $\mathrm{ISI}_{4}$ session is higher than the ISI 2 sessions' $(p=0.05)$ in all electrode areas for the measurements of PPmaxN2P3. For the measurements of PPmaxP3N4, pairwise 
comparisons indicated that ISI 8 session has significantly higher amplitudes than $\mathrm{ISI}_{2}$ session $(\mathrm{p}=0.012)$. ISI8 session has the highest amplitudes for all electrode sites $(\mathrm{Fz}, \mathrm{Cz}$ and $\mathrm{Pz}$ ) in both measurements of for PPmaxn2P3 and PPmaxp3N4 (Figure 3). An increase in amplitudes to non-painful tactile stimuli was observed with the increase of the interstimulus interval for both PPmax 2 P3 and PPmaxp3n4 (Figure 2). Despite the significant amplitude differences, there were no significant effects of electrodes and ISI / electrode interaction in regard to $\mathrm{rm}$-ANOVA results.

A

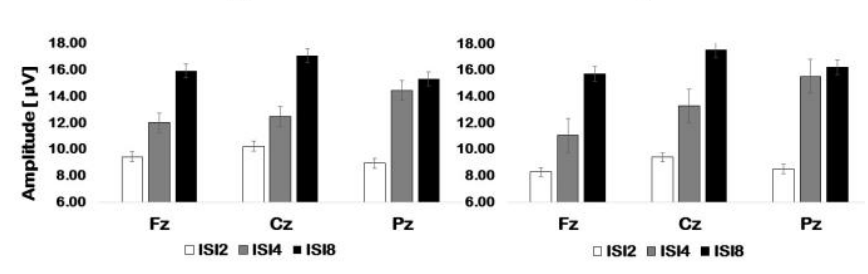

Figure 3: The mean amplitudes of $\operatorname{PPmax}_{\mathrm{N} 2 \mathrm{P} 3}$ (A) and PPmaxp3N4 (B) were demonstrated for three inter-stimulus interval (2s, 4s and 8s) sessions in three electrode areas (Fz, Cz, $\mathrm{Pz}$ ). White bars represent the $\mathrm{ISI}_{2}$ session, gray bars represent the $\mathrm{ISI}_{4}$ and black bars represent the $\mathrm{ISI}_{8}$ session.

\section{DISCUSSION}

The current study aimed to reveal the habituation process on somatosensory system by investigating the brain responses to the nonpainful tactile stimuli with different interstimulus intervals (ISI) $2 \mathrm{~s}, 4 \mathrm{~s}$, and $8 \mathrm{~s}$. Accordingly, the present study revealed that as ISI prolonged the amplitudes increased. In the literature, studies revealed an increase in amplitudes as the ISI increased by using the painful5,8,16,17, vibration ${ }^{6}$ or mechanical (rotation of the hand) stimuli ${ }^{4}$. These stimuli were generally applied to the hand, wrist, arm or leg. In the present study, non-painful tactile stimuli applied to the fingertip. When the stimulus type is considered, electrical stimuli can be evaluated as unnatural. Tactile stimulus is simple and more relevant to the daily life sensory transmission and might be comfortable for the participant compared to the electrical stimuli. Despite the similar neural pathways are involved to the signal transduction, from receptors to the brain, the context of the electrical and tactile stimulus can be evaluated very differently in regard to perception.

In the real world, we are trying to detect the change of the stimulus parameters during the perception. During these processes the hands provides complex interaction with the environment and behave like a sensory detector ${ }^{18}$. People are touching and describing the objects via their fingers neither their elbows nor the wrists ${ }^{19}$.Hence, the stimulation from the elbow, wrist or arm can be evaluated as artificial stimuli, while the stimulus used in the current study was evaluated as a simple touch which was defined as "baby touch" by most of the participants. Non-painful tactile stimulus delivered to limited area of the fingertip. Thus, stimulation of more than one nerve fiber and muscle group was avoided.

In the literature, somatosensory evoked potentials (SEP's) and somatosensory evoked fields (SEF's) were used to investigate habituation process due to the nature of experimental design which contains repetitive stimulations. In one of the oldest studies about the habituation process, mechanical stimuli (rotational) was delivered to the wrist with the different ISIs (0.5s, 1s, 2s, 4s, 8s, and 16s), and as a result, larger ISIs associated with the increased amplitudes ${ }^{4}$.

In another study, possible habituation process was investigated via the painful laser stimuli with different inter-stimulus intervals including $0.5,1,2,4,8$, and 16 seconds. According to the peak-to-peak maximum amplitude measurements, they revealed a significant increase in the amplitudes from the ISI-1s session to ISI-2s session and also from ISI-2s 
session to ISI-4s session. Also, there was a general increase in amplitudes with longer ISIs but these increments were not significant ${ }^{20}$. The studies in which electrical and vibrotactile stimuli were applied to the finger, amplitude increased as ISI increased 21 . The study which performed by Tomberg et al. showed that the N30 component amplitude increased as ISI increased. But there were no significant peak differences (N20, P27, N60, P100 and P200) in long ISIs (1400, 2500 and $4000 \mathrm{~ms}$ ). These studies tried to evaluate the very early and early components of SEP's or SEF's to reveal the habituation process on somatosensory system. In addition to the literature, the present study evaluated the relatively late components of SEP's including the N200, P300 and N400. Current study revealed an amplitude increase when the ISI's (2s, 4s and 8s) are increased. This finding is in line with the previous findings in regard to studies investigated the SEP's and SEF's. In the present study significant increase of the amplitudes were measured between the $\mathrm{ISI}_{2}$ and ISI 8 session.

These findings might be explained by the different type of stimulus. Moreover, very early and early components might be the affected peaks due to the electrical or vibration stimulation, while the late components (N2, P3 and N4) might be the affected peaks due to the non-painful tactile stimuli. Indirectly, it is possible to speculate that the habituation can be observed in the late components of SEP's during the perception of tactile stimuli.

Additionally, there were no significant increase after $4000 \mathrm{~ms}$ of ISI in the literature 20,21 . But current study showed a significant increase in the $8000 \mathrm{~ms}$ of ISI in comparison with the $2000 \mathrm{~ms}$. In our preliminary study we also spotted a $66 \%$ increase of amplitudes in ISI 16 compared with the ISI2. Therefore, we conclude that the significant differences can be observed when the differences between the ISIs were at least four times bigger than each other. To clarify these theories, further studies needed in terms of different ISI's setup.

Conflicts of interest: The authors have no conflict of interests to declare.

Financial Disclosure: The authors declared that this study has received no financial support.

\section{REFERENCES}

1. Klingner CM, Hasler C, Brodoehl S, Witte OW. Excitatory and inhibitory mechanisms underlying somatosensory habituation: Somatosensory Habituation. Hum Brain Mapp. 2014; 35: 152-60.

2. Klingner CM, Nenadic I, Hasler C, Brodoehl S, Witte OW. Habituation within the somatosensory processing hierarchy. Behav Brain Res. 2011; 225: 432-6.

3. Gallace A, Spence C. The science of interpersonal touch: An overview. Neurosci Biobehav R. 2010; 34: 246-59.

4. Angel RW, Quick WM, Curtis Boylls C, Weinrich M, Rodnitzky RL. Decrement of somatosensory evoked potentials during repetitive stimulation. Electroen Clin Neuro. 1985; 60: 335-42.

5. Bingel U, Schoell E, Herken W, Büchel C. A. Habituation to painful stimulation involves the antinociceptive system: Pain. 2007; 131: 21-30.

6. Nangini C, Ross B, Tam F, Graham SJ. Magnetoencephalographic study of vibrotactile evoked transient and steady-state responses in human somatosensory cortex. NeuroImage. 2006; 33: 252-62.

7. Robert Dowman. Interstimulus Interval Has No Effect on a Mid-Latency Scalp Potential Generated by Innocuous-Related Activity in the Primary Somatosensory Cortex. Brain Topogr. 1997; 10: 145-54.

8. Uglem M, Omland PM, Stjern M, Gravdahl GB, Sand T. Habituation of laser-evoked potentials by migraine phase: a blinded longitudinal study. J Headache Pain. 2017; 18: 100.

9. Lehser C, Wagner E, Strauss DJ. Somatosensory Evoked Responses Elicited by Haptic Sensations in Midair. IEEE T Neur Sys Reh. 2018; 26: 2070-7.

10. Forss N, Salmelin R, Hari R. Comparison of somatosensory evoked fields to airpuff and electric stimuli. Electroen Clin Neuro. 1994; 92: 510-7.

11. Ploner M, Pollok B, Schnitzler A. Pain Facilitates Tactile Processing in Human Somatosensory Cortices. J Neurophysiol. 2004; 92: 1825-9.

12. Price DD. Psychological and Neural Mechanisms of the Affective Dimension of Pain. Science. 2000; 288(5472): 1769-72. 
13. McDiarmid TA, Bernardos AC, Rankin CH. Habituation is altered in neuropsychiatric disorders-A comprehensive review with recommendations for experimental design and analysis. Neurosci Biobehav R. 2017; 80: 286-305.

14. Ozgoren M, Erdogan U, Bayazit O, Taslica S, Oniz A. Brain asymmetry measurement using EMISU (embedded interactive stimulation unit) in applied brain biophysics. Comput Biol Med. 2009; 39: 879-88.

15. Jurcak V, Tsuzuki D, Dan I. 10/20, 10/10, and 10/5 systems revisited: Their validity as relative headsurface-based positioning systems. NeuroImage. 2007; 34: 1600-11.

16. Kalita J, Bhoi SK, Misra UK. Is Lack of Habituation of Evoked Potential a Biological Marker of Migraine? Clin J Pain. 2014; 30: 724-9.
17. Wikstrom H, Huttunen J, Korvenoja A. Effects of interstimulus interval on sensory evoked magnetic fields (SEFs) a hypothesis concerning SEF generation at the primary sensorimotor. Electroen Clin Neuro. 1996; 100: 479-87.

18. Benedetti F. Sensory and Motor Functions of the Hand. In: Watt WC, editor. Writing Systems and Cognition: Perspectives from Psychology, Physiology, Linguistics, and Semiotics. Dordrecht: Springer Netherlands; 1994: 347-73.

19. Hayward V. A Brief Overview of the Human Somatosensory System. In: Papetti S, Saitis C, editors. Musical Haptics. Springer International Publishing; 2018: 29-48.

20. Raji TT, Vartiainen NV, Jousmäki V, Hari R. Effects of Interstimulus Interval on Cortical Responses to Painful Laser Stimulation. J Clin Neurophysiol. 2003; 1: 73-9.

21. Tomberg C, Desmedt JE, Ozaki I, Nguyen TH, Chalklin V. Mapping somatosensory evoked potentials to finger stimulation at intervals of 450 to $4000 \mathrm{msec}$ and the issue of habituation when assessing early cognitive components. Electroen Clin Neuro. 1989; 74: 347-58. 